\title{
Rivalitas Arab Saudi Dan Iran \\ Di Timur Tengah Pada Arab Spring Suriah Tahun 2011-2016
}

\section{Mustahyun}

Konsentrasi Kajian Timur Tengah Program Studi Interdiciplinary Islamic Studies Pascasarjana UIN Sunan Kalijaga Yogyakarta

Email:mustahyuntaggala@gmail.com

\begin{abstract}
Conflicts have never been far from Middle East. Arab Saudi and Iran actively involve in the conflict In order to maintain their hegemony and national interest such as in Syria. For instance, in the Arab Spring both countries involved in the proxy war. Saudi supports the opposition movement asking for revolution and resignation of Basar regime while Iran totally supports the Bashar al-Assad. The involvement of both countries in Syria's conflict shows the strategic position of Syria in order to keep Saudi's and Iran's interest and their political power at Middle East. This study aims to explore rivalry of Saudi and Iran at Syria especially in the Arab Spring from 2011 to 2016. There are two main issues to discuss in this study namely how Saudi and Iran participate in the conflict and what is the national interest of both countries encouraging them to participate in the conflict.
\end{abstract}

Keywords: Arab Spring, Syria, Iran, Saudi, Political Interest

\begin{abstract}
Abstrak
Timur Tengah tidak pernah lepas dari konflik. Arab Saudi dan Iran seringkali menjadi aktor yang terlibat konflik. Keterlibatan mereka karena kepentingan national, seperti yang terjadi di Suriah. Konflik Suriah berawal dari gejolak Arab Spring dan menjadi arena Proxy War antara kubu Arab Saudi dan kubu Iran. Arab Saudi mendukung perlawanan Oposisi terhadap rezim, sedangkan Iran totalitas mendukung Presiden Bashar al-Assad. Dukungan Arab Saudi dan Iran dalam bentuk finansial dan militer. Kehadiran Arab
\end{abstract}


Saudi dan Iran, menegaskan bahwa Suriah sebagai wilayah yang sangat strategis dalam mencapai pengaruh politik di Timur Tengah. Tulisan ini bertujuan melihat Rivalitas Arab Saudi dan Iran di Suriah pada peristiwa gejolak Arab Spring tahun 2011-2016. Rivalitas kedua negara tersebut dalam rangka mencapai kepentingan nasional.

Kata Kunci : Arab Spring Suriah, Iran, Arab Saudi, Kepentingan Nasional.

\section{Pendahuluan}

Gejolak Arab Spring yang melanda negara-negara Arab menambah catatan sejarah pertistiwa konflik yang melanda Timur Tengah. Istilah Arab Spring (alrabii' al-arabiy) dan atau Revolusi Arab (al-thauraat al-arabiyyah) adalah dua frase yang mengandung makna berbeda. Arab Spring merupakan suatu proses intelektual atas dorongan yang dibangun dari kesadaran, ide, gagasan dan keinginan rakyat atas pentingya demokratisasi yang tidak terbendung diawali dari media sosial. Sedangkan Revolusi Arab adalah adanya keinginan perubahan dari rakyat bersifat fundamental yang mencakup berbagai bidang dan bersifat kompleks, karena bukan hanya kebebasan berpendapat namun semua aspek kehidupan cukup vital. Seperti tuntutan aktivis Mesir yaitu kesetaraan politik (demokrasi), kesejahteraan, dan membangun martabat (Ibnu Burdah, $2014: 25$ ).
Revolusi Arab juga menjadi peristiwa politik yang dialami oleh rakyat Arab yang berkeinginan merubah tatanan masyarakat yang ideal sebagai bangsa yang mengalami tekanan dari pemimpinpemimpin otoriter, kekuasaan yang tidak terbatas masanya, sehingga terjadi ketimpangan ekonomi dan kesenjangan antara kaum elite dan rakyat miskin. Arab Spring menjalar ke berbagai negara di TimurTengah. Dimulai dari Tunisia menumbangkan rezim Zein AlAbidin Ben Ali, Mesir tergulingnya Husni Mubarak, Libya menurukan penguasa diktator Moammar Khadafi, selanjutnya Yaman, Bahrain dan yang masih berjalan Suriah (Sahide, 2015 : 118-119).

Arab Spring Suriah menjadi pintu masuk konflik yang berkepanjangan antara oposisi yang ingin menjatuhkan rezim dan Pro-Rezim yang tetap ingin memepertahankan Presiden Bashar al-Assad. Konflik Suriah semakin membesar karena banyak tentara yang mengalami 
diserse. Para tentara yang membelok itu meyakini akan jatuhkan Bashar dari tahtanya. Mereka berkaca pada peristiwa Arab Spring di Tunisia, Libya, dan Mesir yang berhasil menjatuhkan penguasa. Atas keyakinan kuat itulah, mendorong para tentara diserse membentuk pasukan Free Syrian Army/FSA (Tentara Pembebasan Suriah). Ini menjadi awal gerakan perlawanan dalam bentuk organisasi militer (Kuncahyono, 2012 : 17).

Selain FSA, ada juga Organisasi Syrian National Council SNC (Dewan Nasional Suriah) yang didukung oleh pihak Barat. SNC berjuang atas demokratisasi dan kemanusiaan. Upaya negosiasi yang dilakukan SNC tidak berhasil dalam menjatuhkan Bashar. Negosiasi selalu berujung kebuntuan, akibatnya perang antara oposisi dan rezim menelan korban jiwa dari rakyat sipil maupun aparat kemanan pemerintah (Sahide, 2015 :124)

Sejak tahun 2012, Bashar alAssad diprediksi akan jatuh dalam waktu dekat. Dari sisi politik maupun lapangan kemampuan Bashar untuk bertahan sudah semakin melemah. Tekanan politik dari berbagai negara-negara di Liga Arab termasuk Arab Saudi dan Qatar sebagai motor penggerak, berupaya mencari dukungan secara internasional untuk menyingkirkan Bashar al-Assad (Burdah, 2014 : 33). Namun kenyataannya tidak demikian, sampai sekarang Bashar Al-Assad masih kokoh di kursi kekuasaannya.

Posisi Bashar al-Assad sebagai penguasa memang kuat. Dari segi politik, ekonomi, dan keamanan dikuasai dari keluarga dekat dan orang-orang Alawit. Bashar menutup pergerakan politik dari berbagai faksi, yang berkuasa hanya partai Bath. Proyek pembangunan infrastruktur Suriah yang diperoleh secara korup dipegang oleh Zou alHima sepupu Bashar. Keamanan di bawah kendali Maher al-Assad, adik Bashar. Ia bertanggung jawab untuk melindungi rezim, menebar kematian, dan kehancuran seperti di Deraa, Rastam, Homs, Jis alShughour, Magya al-Naaman dan Tel al-Kalakh (Kuncahyono, 2004 : 33).

Klan Assad menjadi penguat di seputaran pemerintahan. Terlihat dari posisi strategis baik dalam partai Baath, Pemerintahan, Militer dan Proyek pemerintah dipegang oleh keluarga sendiri. Keluarga berasal dari kalangan Alawit, mereka memanfaatkan kedekatan di lingkaran elite demi kepentingan pribadi. Sehingga korupsi dan nepotisme menjangkit 
pemerintahan. Kondisi ini mengakibatkan presepsi negatif kepada Bashar al-Assad karena berasal dari kalangan minoritas Alawit berafiliasi Syiah. Isu mazhab pun menjadi sangat efektif untuk menyerang rezim klan Assad (Sulaeman, 2013 :21)

Negara yang paling berambisi menjatuhkan Bashar al-Assad adalah Arab Saudi. Melalui Menteri Luar Negeri Arab Saudi, Adel alJubeiri mengatakan; ada dua cara mengakhiri konflik Suriah, yaitu Iran menarik pasukan, berhenti mamasok senjata ke milisi Syiah dan Bashar al-Assad harus mundur dari kursi presiden. Pada prinsipnya, Bahsar al-Assad tidak memiliki masa depan di tangannya. Tuduhan Arab Saudi bahwa Iran terlibat aktif membantu Bashar, mempersenjatai pemerintah Suriah dan mengirim bantuan dari pasukan HizbullahLebanon. Saudi bersikeras melawan langkah Iran dengan memaksimalkan segala potensi yang dimiliki dengan perlawanan politik, ekonomi, dan militer (Republika. co.id, 20/10/2015).

Menteri luar negeri Iran, Ali Akbar Shalehi menuduh bahwa orang-orang asing berusaha menciptakan demonstrasi di Suriah. Presiden Bashar al-Assad dalam pidatonya pada tanggal 30 Marert
2011, mengungkapkan hal yang sama, terjadinya gerakan perlawanan disebabkan konspirasi besar. Alasan itu juga diperkuat oleh Presiden Iran Ahmadinejad pada 10 Mei 2011, pemerintah Suriah sudah pada tahap kematangan dalam menyelesaikan masalah mereka sendiri tanpa membutuhkan intervensi asing. Narasi anti-Barat yang didengungkan Suriah dan Iran memberikan penjelasan tentang posisi mereka dalam menyikapi revolusi Suriah (Trias Kuncahyono, 2012 : 193).

Keterlibatan dua kubu Saudi dan Iran pada konflik Suriah yang berkepanjangan mengindikasikan adanya Proxy War di Timur Tengah. Keinginan Arab Saudi dan Iran untuk memberi pengaruh besar, keamanan wilayahnya serta mendapat keuntungan di Timur Tengah khususnya di Suriah. Kedua kubu harus mengorbankan finansial, pengaruh politik, dan militer. Ini menegaskan bahwa Suriah adalah wilayah yang cukup strategis. Adapun pertanyaan dari penelitian ini, Apa yang melatarbelakangi terjadinya rivalitas Saudi dan Iran di Suriah? Apa kepentingan Arab Saudi dan Iran di Suriah?

\section{Metode Penelitian}

Tulisan ini berfokus pada kajian 
kepustakaan. Dalam kajian ini penulis membaca serta menautkan literatur yang berhubungan dengan tema yang penulis angkat. Fokus kajian terhadap rivalitas Arab Saudi dan Iran dengan objek kajian dikhususkan di Suriah tahun 2011-2016. Peristiwa Arab Spring menjadi pintu masuk konflik berkepanjangan, pertarungan kedua negara tersebut memperparah keadaan Suriah yang memperkuat kubu Oposisi yang didukung oleh Saudi dan rezim Bashar al-Assad yang dipertahankan oleh Iran.

Adapun sumber lain yaitu berupa buku, artikel, berita, dan media online lainnya yang menjadi pendukung data penelitian untuk memahami lebih jauh kepentingan Arab Saudidan Iran diSuriah. Bentuk dukungan Arab Saudi dan Iran pada konflik Suriah memaksimalkan kemampuan bantuan, berupa kucuran dana, bantuan militer dan dukungan politik. Untuk mengurai alasan rivalitas kedua kubu atas kepentingannya diperlukan teori kepentingan nasional. Penulis menggunakan teori kepentingan nasional (national Interest) dalam menganalisis alasan Iran mendominasi Suriah tahun 2011-2016. Donald E. Nuchterlin mengatakan dalam perspektif hubungan internasional, tindakan suatu negara terhadap negara lain tentunya dipengaruhi oleh banyak faktor yang bermuara pada kepentingan nasionalnya masing-masing.

Kepentingan Nasional menurut Donald E. Nuechterlein adalah kondisi di mana kebutuhan dan keinginan yang dirasakan dari satu negara berdaulat dalam kaitannya dengan negara berdaulat lainnya yang terdiri dari lingkungan eksternal. Nuechterlein membagi kepentingan nasional menjadi 4, yaitu; Pertama; Defence interests/ kepentingan pertahanan, yakni perlindungan negara dan warganya ancaman kekerasan fisik yang diarahkan dari negara lain dan atau ancaman terinspirasi dari luar terhadap sistem pemerintahannya. Kedua; Economic interests/kepentingan ekonomi, yaitu peningkatan kesejahteraan atau ekonomi negara melalui hubungan dengan negara lain. Ketiga; World order interests/kepentingan tata internasional yaitu kepentingan untuk maintenance atau mempertahankan sistem politik dan ekonomi internasional yang menguntungkan bagi negara dan warga negara dalam bertransaksi pihak atau negara lain. Keempat; Ideological interests/ kepentingan ideologi, mempertahan atau melindungi/proteksi ideologi negara dari ancaman ideologi 
negara lain (Nuechterlein, 1976 : 247).

\section{Sejarah singkat dan faktor penyebab Arab Spring Suriah}

Pemicu Arab Spring Suriah tidak terlepas dari gerakan rakyat yang menginginkan perubahan secara mendasar seperti sistem yang lebih demokratis, menuntut hak asasi manusia, keadilan, pendistribusian ekonomi secara merata. Rakyat melakukan demonstrasi didasari keyakinan bersama tanpa digerakkan oleh ideologi tertentu, tanpa pemimpin dan tanpa organisasi. Gerakan ini murni dipengaruhi oleh kekuatan media sosial yang tidak terorgansir dan tanpa senjata.

Ketimpangan ekonomi antara penduduk kota dan desa seperti dirasakan di kota Damaskus atau Aleppo. Akibat penerapan sistem ekonomi di bawah kronisme neo-liberal yang dikembangkan rezim Bashar al-Assad. Perekonomian rente yang dikontrol oleh orang-orang yang memiliki hubungan dekat dengan penguasa. Pertumbuhan penduduk yang tinggi dan ketidaktersediaan lapangan pekerjaan salah satu penyebab api revolusi. Usia anak muda yang tergolong usia produktif jumlahnya mencapai seperempat penduduk Suriah, yakni 22 juta jiwa.
Pengangguran lulusan perguruan tinggi mencapai $81 \%$. Pada tahun 1996 pendapatan negara pada sektor minyak mecapai 583.000 barrel perhari, sedangkan tahun 2010 hanya mencapai 385.000 barrel perhari. Kondisi ini membuat perkonomian Suriah di ambang keruntuhan (Kuncahyono, 2004 ; 86).

Pada tahun 2005-2010 kondisi Suriah cukup memprihatinkan, akibat kurang lebih empat tahun mengalami musim kering, curah hujan menurun, semakin langkahya cadangan air. Sekitar 162 Desa di Suriah pada tahun 2007-2008 ditinggalkan penduduknya. Di bagian timur Suriah sekitar 85\% binatang ternak mati antara periode tahun 2005-2010 akibat musim kering. Kondisi ini mengakibatkan petani tidak bisa menjalankan aktivitasnya, akibatnya para petani meninggalkan daerahnya dan bermigrasi ke kota-kota. Di kota mereka membangun gubuk-gubuk. Mereka kesulitan mendapatkan pasokan air, listrik, kesehatan. Ditambah lagi anak-anaknya tidak mengenyam pendidikan. Penumpukan penduduk terjadi di Deraa dan kota-kota di wilayah Hawran, kurang lebih 1,4 juta jiwa. Eksodus ini menjadi salah satu alasan mengapa pusat-pusat 
perlawanan rezim berada di daerah tersbut (Kuncahyono, 2004 ; 92).

Arab Spring Suriah berawal dari kota kecil Deraa. Sepenggal kalimat graffiti yang tertulis didinding "al-shaab yureed isqat al-nizam" (rakyat ingin menumbangkan rezim), pelakunya adalah 15 anakanak sekolah yang masih berumur 15 tahun. Akibatnya anak sekolah tersebut ditangkap oleh aparat keamanan yang dipimpin Atef Najib, sepupu Presiden Bashar alAssad. Anak-anak itu dihukum dengan mencabut kuku jemarinya. Ketika orang tuanya melakukan protes, Atef Najib mengatakan "Forget your children. Go sleep with your wives and make new ones, or send them to me and I'll do it'. Penyiksaan terhadap anak-anak itu sontak mengundang demonstran melakukan protes perlawanan di Mesjid Omari kurang lebih seribu orang (Robin and Leila, 2016 : 38).

Bentuk vandalisme di dinding sekolah itu tidak muncul begitu saja, tapi anak-anak terpengaruh oleh apa yang mereka lihat di televisi. Slogan itu diteriakkan saat berkobar revolusi Mesir dan Tunisia. Kemarahan rakyat Suriah atas perlakuan aparat keamanan menjadi konflik berdarah. Konflik yang berjalan lebih dari setahun Arab Spring menelan korban 25.000 orang dan ribuan orang mengungsi. Perlawanan rakyat Suriah terus bergerak dari kota-kota pinggiran hingga menjalar ke kota besar, Damaskus dan Aleppo. Bentuk perlawanan kepada rezim semakin terorganisir setelah dibentuk kelompok Free Syirian Army/FSA pada tahun 2012 yang didukung oleh tentara pembelot termasuk seorang jendral, Mohammad Sillu (Kuncahyono, 2012: 16)

Selain kelompok oposisi FSA, ada juga Syrian National Council/ SNC, anggotanya sebagian besar dari Ikhwanul Muslimin, tokoh Kurdistan dan tokoh sekuler lainnya. SNC beraliansi dengan FSA, tugas SNC mencari finansial dan bantuan senjata dari pihak internasional, diantaranya Arab Saudi, Qatar, Turki, Prancis, Inggris dan Amerika (Dina Y. Sulaeman, 2013: 109). Peran SNC semakin diakui oleh Liga Arab, yang dimotori Arab Saudi. Mouaz al-Khatib adalah menjadi peserta resmi dari Suriah pada Konfrensi Tingkat Tinggi Liga Arab di DohaQatar tahun 2013. Dari keterangan al-Khatib menginginkan bantuan untuk melawan kekejaman rezim Bashar al-Assad. Al-Khatib juga meminta langsung kepada Amerika untuk melakukan serangan dan rudal kepada penguasa Suriah (Kompas.com, 27/03/2013). 
Konflik Suriah semakin krusial setelah muncul kelompok jihadis yang juga menginginkan Bashar Al-Assad mundur. Kelompok Jabhat al-Nusrah (afiliasi alQaedah) dideklarasikan tahun 2012. Al-Nusrah melakukan pengeboman di Damaskus bulan Juli 2012. Kelompok pemberontak Bashar al-Assad ini berkarakter moderat dengan komunitas lokal sehingga bisa diterima di kalangan masyarakat baik Muslim maupun non-Islam. Al-Nusrah tidak menyerang kelompok minoritas bahkan mereka melindungi gereja, mereka menunjukkan bahwa al-Nusrah kelompok sosial-religius, bukan kelompok takfiri. Pemimpinya adalah al-Jawlani (Weiss, Hassan, 2015 : 169).

Berbeda dengan ISIS, kelompok jihadis ini sangat ekstrem dan radikal. Mereka menyerang gereja. Diklaim sebagai pasukan terkuat ke tiga dalam konflik Suriah, melakukan pemboman sekolah, rumah sakit dan pasar di Raqqa. Mereka juga melakukan transaksi jual beli minyak dengan jihadis lain. Pemimpinnya adalah Abu Bakar alBaghdadi (Robin and Leila, 2016 : 132). Akibat akasi yang dilakukan ISIS dan Jabhah al-Nusrah di Suriah, mereka di cap sebagai teroris. Namun Mouaz al-Khatib pemimpin Syrian National Council/ SNC meminta kepada Amerika dan Australia mencabut tuduhan kepada Jabhah al-Nusrah (Ali, 2014 : 334).

Pada tanggal 19 Mei 2011, Presiden Amerika Serikat Barrack Obama memberi tawaran yang sangat agresif kepada pemerintah Suriah. Bashar al-Assad harus memilih transisi damai ke demokrasi atau memilih mundur dari kekuasaan. Dewan Keamanan PBB mengusulkan resolusi untuk mengecam akibat pelanggaran hak asasi manusia yang dilakukan secara sistemik dan berat. Namun usulan itu ditolak oleh anggota DK PBB yang memiliki hak veto yaitu Rusia dan China. Sedangkan yang mendukung adalah Amerika Serikat, Prancis dan Jerman. Pada 5 Februari 2012, Presiden Barack Obama mendesak Bashar al-Assad untuk segera mundur. Adapun yang ikut mendukung resolusi $\mathrm{PBB}$ yaitu negara-negara Barat dan Liga Arab yang mengecam tindakan Bashar, sebab dinilai kejam terhadap demonstran. (Kuncahyono, 2012 : 175).

Rusia semakin kokoh berpihak kepada Suriah. Dukungan yang diberikan Rusia terhadap Suriah berupa bantuan militer, senjata perang dan mengirim pesawat tempur. Rusia dan Suriah 
bekerjasama di berbagai bidang, termasuk kesepakatan bahwa Rusia akan membangun infrastruktur gas dan minyak serta mengembangkan pusat energi nuklir. Rusia juga memiliki pangkalan militer di Tartus. Satu satunya pangkalan angkatan laut yang sudah digunakan sejak perang dingin yang diikat perjanjian pada tahun 1971. Rusia menjadikan Suriah sebagai klien dalam hal transaksi jual beli senjata yang mencapai 1,5 miliar dollar AS. Prinsip utama Rusia adalah menentang setiap usaha dari luar untuk mengintervensi kedaulatan Suriah (Kuncahyono, 2012 : 186).

Perebutan kekuasaan di Suriah semakin memperparah konflik antara Oposisi dan rezim Bashar. Ini akibat pertarungan secara global antara Amerika-Rusia dan pertarungan kekuasaan serta reputasi antara Arab Saudi-Iran di kawasan regional. Perbedaan sikap kedua kubu membuat suriah semakin rumit, Arab Saudi berpendapat bahwa yang harus diproritaskan di Suriah adalah transisi pemerintahan. Sedangkan Iran berpendapat bahwa masalah terorisme harus dibahas terlebih dahulu sebelum membahas pemerintahan transisi. Silang pendapat ini terjadi ketika perundingan damai di Genewa awal
Februari 2014 (Ali, 2014 : 328-335).

Rivalitas Arab Saudi dan Iran di Suriah

\subsection{Kepentingan Ekonomi-Politik}

Kebijakan politik luar negeri Iran untuk mendukung Bashar al-Assad merupakan balasan atas bantuan Suriah kepada Iran sejak meletusnya perang Irak-Iran tahun 1980-1988. Sikap politik mendiang Ayah Bashar al-Assad, Hafes alAssad menjadi pertimbangan kuat Iran tidak bisa lepas dari Suriah. Pada perang Iran-Irak, Suriah bersama Libya dan Yaman Selatan menjadi satu kubu, sedangkan di kubu Irak terdapat Mesir, Yordania, Yaman Utara, GCC, AS/Barat, Maroko, PLO dan Uni Soviet (Noor, $2014 ; 387)$.

Suriah adalah negara yang paling pertama menyatakan dukungan kepada Iran sejak jatuhnya rezim Shah Pahlevi 1979. Hafes al-Assad mengirim surat telegram kepada Khomeini, dalam pesannya Hafes memuji kemenangan rakyat Iran. Hafes mengirim Rif'at sebagai komandan pertahanan Suriah untuk membahas kerjasama. Teheran membalas kunjungannya dengan membicarakan strategi mendukung oposisi Irak yang mayoritas kaum Syiah Irak Selatan. Kemudian menyusul pernyataan dukungan 
untuk pemimpin baru Teheran, dari Libya, Aljazair, Yaman Selatan dan PLO. Sedangkan negara tetangga seperti Irak, Arab Saudi, Yordania dan Mesir merasa khawatir atas kemenangan Khomeini. Sikap Khomeini terhadap negara-negara Arab cukup keras, termasuk kepada Mesir yang melakukan perjanjian kerjasama dengan Israel dan hubungan dekat antara MesirAmerika. Khomeini memutuskan hubungan diplomatik dengan Mesir. Kebijakan yang dilakukan Khoemini ini mendapat simpatik dari Hafes alAssad, Suriah menemukan sekutu untuk melawan Israel (Goodarzi, $2006 ; 18)$.

Pascarevolusi Iran 1979, hubungan Iran dan Barat mulai retak. Munculnya Imam Khomeini sebagai tokoh revolusioner mengubah wajah Iran secara total dari awalnya mendukung Amerika hingga berbalik membenci, ketidaksukaan itu ditunjukkan dengan mengambil alih sejumlah Kedutaan Besar. Termasuk keduataan Israel direbut dan diserahkan kepada Palestina. Semua aset negara yaitu perusahaan minyak yang dikusai Amerika dinasionalisasikan oleh penguasa baru Iran. Di awal revolusi, Iran sulit menjalin hubungan dengan negara-negara lain. Slogan yang dikumandangkan Imam Khomeini tidak barat dan tidak timur, artinya tidak Amerika dan tidak Uni Soviet. Iran mengalami perbuhan setelah masa Presiden Hashemi Rafsanjani (987-1997) karena sikapnya mulai melunak dan mendorong rekonsiliasi. Hubungan negara lain semakin membaik pada saat Presiden Khatami, ia melakukan kunjungan ke Italia dan Prancis pada maret 1999, ini sebagai kunjungan bersejarah sejak menjadi negara republik Islam Iran (Sahide, $2013 ; 100)$.

Pada masa kepemimpinan Ahmadinejad sebagai Presiden Iran tahun 2005 semakin merenggang. Iran mengembangkan program nukilirnya yang dianggap oleh Amerika sebagai ancaman kestabilan sistem serta kepentingan Amerika sebagai negara paling berpengaruh di Timur Tengah. Ketidaksukaan Amerika kepada Iran juga diikuti oleh negara-negara sekutunya termasuk Saudi, Mesir. Hingga pada tahun 2007, Iran mendapat sanksi terkait nuklirnya dari Dewan Keamanan PBB dengan resolusi 1747 . Ini akibat besarnya pengaruh Amerika dalam mengatur keluarnya resolusi tersebut (Sahide, $2013 ; 101)$.

Sanksi ekonomi dan embargo perdagangan yang terus dialami Iran oleh Amerika dan sekutu- 
sekutunya tidak menghalangi Iran memperbaiki sektor ekonomi dan infrasturkurnya. Iran berhasil memacu pertumbuhan dan perkembangan ekonomi hingga ke 17 dunia pada tahun 2011 sebagaimana dilaporkan statistik IMF. Iran berhasil mengimpor bahan pangan dan bahkan sejak 2011 Iran mengekspor gandumnya ke berbagai negara. Pendapatan negara tidak hanya dari sektor migas namun sektor non migas terus meningkat tajam menjadi USD 105 miliar pada tahun 2012 (Heriyanto, $2013 ; 26)$.

Kebijakan pemerintah Iran membantu Presiden Bashar dalam mempertahankan posisinya sebagai penguasa Suriah merupakan langkah tepat, sebagai salah satu jalan memperkuat sekutu di kawasan Timur Tengah. Iran melihat Arab Saudi terus membangun koalisi negara-negara teluk dalam rangka melemahkan Iran dari berbagai sektor. Ajakan Saudi terhadap anggota GCC yaitu Qatar, Kwait, Bahrain, Oman dan Uni Emirat Arab (UEA) untuk menghentikan hubungan dengan Iran. Nilai perdagangan Iran dengan GCC mencapai 22 miliar dollar AS (Kompas, 09/01/2016).

Untuk tetap menstabilkan perekonomian, Iran terus berusaha menjalin kerjasama negara lain, pilihanya adalah Suriah. Mengingat kondisi geografis Suriah merupakan negara terdekat dan wilayahnya sangat strategis yaitu menembus transaksi perdagangan dengan negara-negara Eropa dan Afrika. Maka pada tahun 2011 Iran dan Suriah menandatangi kesepakatan gas alam senilai 10 miliar dollar AS. Termasuk melibatkan Irak dalam kesepakatan ini. Pembangunan pipa gas alam dari Iran melewati Irak hingga Suriah sampai ke Mediterania serta Lebanon. Keuntungan yang didapat akan dibagi sebagaimana Irak mendapat 20 juta meter kubik gas alam perhari, Suriah 20-25 juta meter kubik perhari. Sebenarnya proyek besar Iran sudah berjalan sejak tahun 2008 dengan nilai proyek sebesar 1,3 miliar dollar AS (Kuncahyono, 2012; 192).

Arab Saudi gagal menjinakkan Suriah sebagai mitra ekonomi meskipun Suriah tergabung dalam Liga Arab. Harapan terbesar Saudi menjadikan Suriah sebagai akses utama perdagangan minyak melalui pipanisasi menjadi terhalangi akibat kokohnya Bashar al-Assad di Suriah. Tujuan Arab Saudi menjatuhkan Bashar sejalan dengan tuntutan pihak Oposisi. Kepentingan utama Saudi yang didukung oleh Amerika acces to oil. Amerika berusaha 
keras mendapat pasokan minyak yang lebih banyak dikarenakan kebutuhan domestik sekitar 19,150 juta barrel perhari. Salah satu pemasok terbesarnya adalah Arab Saudi (ismes.net, 02/02/2017).

Stabilitas ekonomi Saudi tergantung dari sektor minyak. Kondisi ekonomi Saudi terganggu pasca-anjloknya harga minyak dunia. Pada tahun 2014 US\$ 100 per barel menjadi sekitar US\$ 50 per barel. Akibatnya pendapatan Saudi menurun hingga 70\%. Saudi mengatur strategi yaitu menjual sebagian saham sekitar 5\% Saudi Aramco, Badan Usaha Milik Negara dengan taksiran harga US\$ 2,5 triliun atau sekitar 32.500 triliun. Ketidakstabilan ekonomi Saudi mengharuskan melakukan pemutusan hubungan kerja/PHK sekitar 50.000 pegawai, salah satunya perusahaan konstruksi, Saudi Binladin Group (Finance. detik.com, 27/02/2017).

Arab Saudi juga mengeluarkan banyak anggaran negara untuk kepentingan perang di Yaman dan Suriah. Di Yaman pemerintah Saudi berjuang melawan pemberontak Houthi yang mengancam keamanan wilayah Saudi bagian selatan. Sedangkan di Suriah ikut serta membantu serangan udara melawan ISIS. Dana moneter International
(IMF) memperkirakan Saudi akan mengalami defisit hingga tahun 2020 (ekonomi.kompas.com, 08/08/2015).

\subsection{Kepentingan Sekte/Ideologi Sunni-Syiah}

Arab Saudi dan Iran merupakan dua negara dengan kekuatan politik yang berpengaruh di Timur Tengah, karena perbedaan sekte antara Sunni-Syiah. Ketidakharmonisan kedua negara semakin parah ketika Iran berhasil mensukseskan agenda Revolusi Islam Iran pada tahun 1979. Di sisi lain, Iran merupakan negara dengan penduduk mayoritas Syiah (89\%) sedangkan Arab Saudi mayoritas penduduknya Sunni (95\%). Perbedaan aliran keagamaan dalam Islam tersebut yang menjadi salah satu pemicu lahirnya "perang dingin” (Sahide, 2017 : 162). Meskipun bersumber dari Islam, namun ketegangan di Timur Tengah adalah realitas sektarian, bukan keagamaan. Dimensi ekonomi dan politik sektarianisme lebih kentara dibanding dimensi spiritualitasnya. (Barakat, 2012 : 169).

Gerakan revolusi Islam Iran tahun 1978-1979 yang diinisiasi kaum Syiah, memberi pengaruh besar terhadap perkembangan politik Dunia Islam, terutama di kawasan Timur Tengah. Negaranegara di Timur Tengah meng- 
alami keguncangan akibat munculnya gerakan-gerakan Islam fundamentalis, radikal, militan dan ekstrem. Gerakan-gerakan semacam itu yang di beberapa negara cenderung anti-kemapanan, dan biasanya disbut sebagai kelompok-kelompok Iran (Sihbudi, 1991 : 191).

Pemimpin Revolusi Imam Khomeini sangat kental dengan keSyiah-annya sehingga menimbulkan rasa takut bagi negara-negara Timur Tengah. Rovolusi Islam Iran menjadi sumber inspirasi dan motivasi bagi negara-negara yang memiliki populasi penduduk minoritas kaum Syiah dan mayoritas Sunni, seperti Arab Saudi. Ada keinginan kuat dari kaum Mulla menjadikan Iran sebagai simbol perlawanan Islam dan Iran memiliki khazanah budayanya sendiri sebagai IslamSyiah (Sahide, 2013 : 92).

Kebangkitan Syiah di negaranegara Arab dengan istilah alsahwah al-Islamiyyah sebagaimana yang digencarkan Iran dan Hizbullah. Kesan dari istilah ini mengacu pada makna umum yaitu kebangkitan atau kesadaran Islam. Namun maksud yang sesungguhnya adalah kebangkitan pengaruh revolusi Islam Iran di negara-negara Arab. Iran berusaha menebar pengaruh revolusi Iran
1979 di kawasan Timur-Tengah. Iran menyuarakan kebangkitan kesadaran Islami yang menuntut keadilan global dan penegasan paksa politik perlawanan terhadap Barat dan Israel (Burdah, 2014 : 25).

Usaha Iran memberi pengaruh di Timur Tengah juga ditunjukkan di Suriah. Bantuan militan Syiah sangat membantu Bashar al-Assad dilapangan untuk menekan lawanlawan yang akan menjatuhkan tahtanya. Sejak revolusi Khomeini di Iran, aliansi Suriah-Iran di bawah kepemimpinan Hafes alAssad hanya fokus pada persamaan dalam hal keyakinan dan politik, serta menghilangkan segala bentukbentuk perbedaan. Meskipun keduanya berbeda mazhab Syiah, bagi Iran itsna asyari dan Suriah mazhab Alawith Nashiri. Hal ini juga diperkuat oleh pemimpin Syiah Lebanon, Musa Shadr. Ia menyatakan bahwa Mazhab Alawit adalah Mazhab Syiah. Pada masa Presiden Hafes, ia sering memintanya untuk mendakwakan mazhab Itsna Asyari di kalangan alawiyyin. Ini salah satu cara kedua negara menjadi aliansi solid di kawasan Timur Tengah. Di bawah payung ke-Syiah-an, mereka menyingkirkan perbedaan. Hingga Arab Spring tiba mereka mampu bersatu dalam pasukan-pasukan 
militan bersama Hizbullah, Laskar Yaumul Mau'ud, dan Rabithatul Haq, mereka berjuang bersama mempertahankan kekuasaan Bashar al-Assad (Liputanislam.com 23/04/2014).

\section{Iranian Revolutionary Guard} adalah salah satu tim dari Iran yang membantu melatih tentara rezim dengan sebutan National Defense Force. Milisi ini beranggotakan 70.000 orang dari kalangan warga Alawi-Syiah Suriah. Juli 2013 Suriah mendapat sokongan dana sebesar \$3,6 miliar dari Iran. Dalam analisis Scott Lucas, Iran merupakan bagian terpenting dalam menopang rezim Bashar yang tidak mampu memenuhi keinginan serta kebutuhan dasar rakyatnya. Iran memiliki kedekatan secara sekte bagi Bashar yang berasal dari golongan Alawi yang berafiliasi Syiah meskipun diklaim penyimpangan di dalamnya, karena bagi kaum Sunni, Alawit itu sesat. Sejak tahun 1980 Iran menjadikan Suriah sebagai jalur bantuan terhadap pasukan Hizbullah di Lebanon. Posisi Suriah secara geografis adalah jalur utama Iran untuk menguatkan pasukan Hizbullah sebagai garda terdepan dalam menolak pendudukan Israel (Robin, Leila, 2016; 198).

Salah satu isu yang mengindikasikan hubungan erat antara
Iran-Suriah adalah menginisiasi kerjasama dalam bentuk diplomasi budaya, wisata religi, promosi bahasa, lembaga resmi. Sejak tahun 1980 an keduanya resmi melakukan kesepakatan pertukaran budaya, hubungan mereka dinaungi oleh keduataan besar masing-masing negara. Seperti kegiatan keduataan Iran mempromosikan budaya dan bahasa Persia, hingga menjadi bahan pelajaran di Universitas Damaskus dan Aleppo. Bagi Iran hal menarik di Suriah adalah wisata religi atau ziarah kubur ke makam Sayyida Zaynab dan Sayyida Rugayya (Ahlul Bait). Wisatawan Iran peminatnya sangat tinggi sejak 1950-an. Kaum Syiah Iran selain Irak menjadi pilihan destinasi wisata, Suriah juga menjadi populer. Sebaliknya kaum Syiah Suriah juga sering mengunjungi pusat kebudayaan di Iran (Maltzahn, 2013 ; 3).

Konflik Suriah menjadikan Teheran untuk pertama kalinya menunjukkan kekuasaan di kawasan Timur Tengah, membentang dari Irak dan Suriah hingga Lebanon. Dominasi Iran ini melahirkan istilah Bulan Sabit Syiah. Konsep Sabit Syiah adalah penyebaran pengaruh regional membentang seperti membentuk sabit, mulai dari perbatasan Afganistan sampai ke laut Mediterrania. Selama bertahun- 
tahun istilah ini begitu diwantiwanti dan menjadi kekhawatiran oleh sejumlah negara-negara Timur Tengah yang penduduknya mayoritas muslim Sunni, khususnya Arab Saudi (CNNIndonesia.com, 15/12/2016).

Astrid B. Boening menjelaskan populasi masyarakat Suriah secara sekte :

"The interwoven complexity of regional ideology on war and peace in the MENA is exemplified in Syria's sectarian pluralism, with $75 \%$ Sunni Muslmi (including Sufis), approximately $10 \%$ Shia Muslim, mostly of the Alawith sect, 10\% Christians, 3\% Druz, some Jews, plus some minor Islamic sect (Lesch 2013, p. 83). The Al-Assad regimes have successfully played the minority card, warning the threat of majority rule and the price of instability which the minorities must bear" (Lesh 2013) (Boening, 2013 : 49).

Anggapan Saudi bahwa rezim Bashar menindas rakyat Suriah mengundang simpatik dari pengusaha yang dimotori perusahaan National Fundraising Campaign For Syirian dan donatur lainnya seperti Putra Mahkota Salman, Deputi Pertahanan
Saudi sebesar 10 juta SR, Al-Rajhi Bank sebesar 5 juta SR, Mobily perusahaan operator seluler Saudi sebesar 3,4 juta SR. Tujuan bantuan dana tersebut untuk membantu oposisi Suriah (www.tribunnews. com/internasional, 07/26//2012).

Saudi beralasan bahwa masyarakat Suriah mayoritas Sunni yang butuh keselamatan dari pembantaian pemerintah Bashar. Isu sekte yang dibangun oleh Saudi cukup berhasil memberi pengaruh terhadap masyakarat oposisi Suriah, untuk membangkitkan semangat perlawanannya terhadap rezim Bashar. Sedangkan kaum minoritas dari Alawith berafiliasi Syiah sukses membangun konsolidasi dalam memepertahankan Bashar. Bashar membangun kekuatan militer dengan mendudukkan pejabatpejabat militernya dari sekte yang sama, terlebih lagi dari keluar dekat penguasa (Burdah, 2014 : 39).

\section{Aliansi Politik}

Untuk mengukur kedekatan hubungan antar satu negara dengan negara yang lain dapat dilihat dari aliansi politiknya. Maka penulis juga mencoba membahas hubungan Arab Saudi dan Iran dengan Barat melihat konteks konflik Suriah.

\section{Aliansi Suriah-Iran-Rusia}

Rusia, China dan Iran berada 
dalam satu gerbong mendukung pemerintahan Bashar al-Assad. Rusia memiliki kepentingan mengamankan pangkalan angkatan laut. Satu-satunya pangkalan angkatan Laut Rusia di laut tengah hanya ada di Suriah yaitu Pelabuhan Tartus. Sejak berdiri Uni Soviet 1970-an Suriah selalu mendapatkan bantuan perlengkapan militer pada masa pemerintahan Hafes al-Assad. Berlanjut masa Bashar al-Assad, persahabatan Rusia-Suriah semakin erat, dalam pertemuan Vladmir Putin dan Bashar al-Assad sepakat bekerjasama di bidang minyak dan gas. Keduanya bersepakat dan menandatangani kontrak untuk pembangunan kompleks petrokimia. (Kuncahyono, 2012 : 180).

Sejak peristiwa Revolusi Rakyat Suriah 2012, Rusia tidak ingin Bashar turun dari tahtanya, seperti pemimpin di Tunisia, Mesir dan Libya. Maka pada 17 Agustus 2011, Rusia mengirim senjata ke Suriah meskipun mendapat protes keras dari pihak internasional. Sejak tahun 2000-2010 nilai penjualan senjata Rusia ke Suriah mencapai 1,5 miliar dollar AS. Semua resolusi dan sanksi yang dijatuhkan PBB semua dibalas dengan veto. Prinsip utama Rusia yaitu menentang setiap usaha dari luar untuk mengintervensi kedaulatan Suriah. Kekhawatiran terbesar Rusia jika Bashar al-Assad turun tahta, maka dipastikan penggantinya akan meninjau ulang kesepakatan yang telah berjalan (Kuncahyono, 2012 : 185).

Rusia dan Iran mempunyai kepentingan yang sama di Suriah. Rusia tidak mendapatkan kendala bekerjasama dengan Iran dalam aliansi mempertahankan Bashar al-Assad. Hubungan Rusia-Iran dalam berbagai bidang telah berjalan lama. Pada tahun 1995 Rusia memberi bantuan sebesar 800 milyar dollar untuk mengembangkan reaktor nuklir Iran. Rusia juga membantu 2000 metric ton natural uranium. Selama proses pengerjaan pengembangan nuklir Iran mendapat tekanan dari pihak Barat tertama Amerika. Atas desakan dari pihak luar, Iran dalam pembagunan nuklir mengalami banyak proyek yang tertunda. Rusia juga memerlukan pasokan minyak dari negara-negara Timur Tengah. Bagi Rusia, memilih Iran sebagai mitra adalah hal yang paling tepat, alasan letak geografis sebagai tetangga, Iran merupakan pintu masuk di Timur-Tengah. Target Rusia 25 juta ton pertahun, namun yang berjalan masih skala kecil 2,53 juta ton pertahun (Akbar, 2015 : 5-7). 
Agar kuota terpenuhi minyak terpenuhi Iran mendapat peluang di Suriah sebagai mitra yang menguntungkan. Pada 25 Juli 2011, Iran-Suriah menandatangani kesepakatan membangun gas alam dari Iran ke Suriah. Pada 19 Agustus 2008, Menteri Indusrtri dan pertambangan Iran, Ali Akbar Mehrabin menyatakan bahwa Iran memiliki ragam proyek senilai 1,3 miliar dollar AS di Suriah. (Kuncahyono, 2012 : 192). IranSuriah dalam pengembangan kerjasama di berbagai bidang terus berkembang, termasuk perdagangan minyak peluangnya sangat terbuka.

Dalam kasus konflik Suriah, Teheran berpendapat bahwa pergolakan di Suriah dilakukan oleh Amerika, Israel dan sekutusekutunya untuk melemahkan Iran dan sekutunya di Timur-Tengah. Teheran sepakat apa yang dikatakan Damaskus bahwa persoalan konflik yang semakin membesar disebabkan kekuatan eksternal dan konspirasi internasional. Menlu Iran, Ali Akbar Salehi tegas menyatakan bahwa orang-orang asing berusaha menciptakan demonstran di Suriah (Kuncahyono, 2012 : 193)

\section{Aliansi Arab Saudi-Liga Arab- Amerika}

Sejak 22 April 2011, Amerika, dalam hal ini adalah Presiden
Barrack Obama mendorong Bashar al-Assad untuk melakukan perubahan ke arah yang lebih baik dan Obama berharap Bashar menghormati hak-hak asasi manusia rakyat Suriah. Obama semakin agresif menekan Bashar alAssad, ia mengatakan Bashar harus memilih atau memfasiltiasi transisi damai ke demokrasi atau memilih mundur dari jabatan. Tekanan yang dilakukan Amerika di ikuti Uni Eropa, dipimpin Inggris, Jerman, Swedia, dan Belanda, menjatuhkan embargo senjata serta sanksi dan larangan perjalanan seluruh anggota rezim Bashar al-Assad (Kuncahyono, 2012: 175).

Sekutu Amerika di Timur Tengah yaitu Arab Saudi mengambil sikap tegas dengan mengecap Bashar al-Assad untuk mundur. Melalui Menteri Luar Negeri Arab Saudi, Adel al-Jubeiri mengatakan; ada dua cara mengakhiri konflik Suriah yaitu Iran menarik pasukan, berhenti mamasok senjata ke milisi Syiah dan Bashar al-Assad harus mundur dari kursi presiden. Pada prinsipnya, Bahsar al-Assad tidak memiliki masa depan ditangannya (Republika.co.id, 20/10/2015).

Sejak 2011, Arab Saudi dalam hal ini, Raja Abdullah secara terbuka mengecam pemerintah Suriah, berkitan dengan perlakuan 
Damaskus terhadap demonstran. Raja Abdullah mengatakan, apa yang terjadi di Suriah tidak dapat diterima oleh Arab Saudi dan semakin terjerumus dalam pergolakan. Arab Saudi menarik duta besarnya dari Suriah, dan menyeru agar pemerintah Suriah menghentikan mesin pembunuhnya (Kuncahyono, $2012: 210$ ).

Dalam kasus Suriah, Arab Saudi bekerjasama dengan Amerika dengan memperalat Liga Arab untuk mengisolasi Bashar al-Assad dari kancah politik dunia Arab. Sebagai bukti dalam Konferensi Tingkat Tinggi (KTT) pada tahun 2013, Liga Arab menerima delegasi resmi dari Suriah dari kelompok Oposisi yaitu Muoz al-Khatib (Sahide, 2017 : 164). Muoz al-Khatib juga meminta kepada Amerika dan Australia untuk mempertimbangkan kembali keputusannya terhadap Jabhah alNusrah sebagai kelompok teroris di Suriah (Ali, 2014 : 334).

\section{Kesimpulan}

Gejolak Arab Spring yang berawal dari kota kecil Deraa mampu menjalar ke kota-kota besar dan meluas ke segala penjuru Suriah. Api revolusi berawal dari sekelompok anak-anak sekolah dengan coretan di dinding bermaksud untuk mengganti rezim yang berkuasa. Respons aparat keamanan Bashar al-Assad melampaui batas kemanusiaan sehingga menyulut pergerakan massa demonstran menuntut keadilan. Ketidakseimbangan peralawanan antara masyarakat sipil dan aparat mengakibatkan korban banyak berjatuhan. Bashar al-Assad menuduh pihak asing yang menunggangi lahirnya Arab Spring, kemudian lahir kelompok anti-Bashar yaitu Oposisi.

Oposisi dari berbagai kalangan, dari kelompok yang diakui secara internasional maupun kelompok jihadis yang kesemuanya ingin menumbangkan rezim. FSA (Free Syrian Army) adalah organisasi yang terbentuk dari tentara yang pernah bekerja di pemerintahan dan kini membelok melawan Bashar al-Assad. SNC (Syrian National Council) yang anggotanya sebagian besar aktivis Ikhwanul Muslimin. SNC mendapat bantuan dari Amerika, Inggris, Prancis, Turki, Qatar dan Arab Saudi. Namun Amerika menilai SNC tidak efektif dalam melakukan perubahan di Suriah. Kemudian berubah menjadi SNCORF (Syrian National Coalition for Opposition and Revolutionary Forces) yang di pimpin oleh Moaz alKhatib. Sebagai bentuk pengakuan kepada Moaz al-Khatib, ia menjadi 
delegasi dalam Konfrensi Tingkat Tinggi Liga Arab tahun 2013 di Doha.

Pada keputusan organisasi Liga Arab, yang paling berpengaruh adalah Arab Saudi. Kesempatan mendukung Oposisi sebagai langkah tepat untuk menurukan Bashar al-Assad dari posisinya sebagai presiden. Suriah merupakan salah satu anggota Liga Arab, namun kedekatan dengan Iran membuat Suriah sulit dikendalikan. Arab Saudi tidak mendapatkan posisi kerjasama dengan Suriah, yang mana wilayah Suriah sangat strategis dalam perdaganan minyak. Jalur pipa minyak dan gas daerah Suriah sampai Mediterania dan menembus pasar Eropa mampu menambah penghasilan negara.

Iran memiliki kedekatan dengan Bashar al-Assad, secara sekte ke-Syiah-an. Iran mayoritas Syi'ah-Itsna Asyariah dan Bashar Syi'ah-Alawith. Meskpun berbeda namun keduanya hanya melihat persamaan. Perjanjian kerjasama diberbagai bidang tercapai terutama bidang ekonomi, seperti kerjasama pembuatan pipa minyak dan gas. Masing-masing mendapat keuntungan, dan dipastikan Iran mendapat tambahan finansial. Suriah merupakan negara Arab yang masih bertahan dan paling terdepan menentang Israel. Bagi Suriah, tidak ada kata damai untuk Israel. Sejalan dengan Iran yang sangat menentang Israel. Dukungan Iran terhadap Hizbullah di Lebanon merupakan bentuk perlawanan Iran. Dukungan finansial dan peralatan militer akan mudah karena Suriah menjadi akses utama.

Iran semakin menancapkan kekuatannya ke jantung Timur Tengah. Kekhawatiran itu yang dialami Arab Saudi. Iran dengan jaringan sekte Syiah mampu memberi pengaruh terhadap kondisi keamanan Arab Saudi. Gerakan politik kelompok Syi'ah di Saudi dengan menutut hak politik di wilayah kekuasaan kerajaan. Arab Saudi lalu merespons secara keras dengan menghukum mati ulama Syiah Syekh Nim'r al-Nimr karena dianggap memprovokator massa. Warga Iran lantas merespons dengan merusak kedutaan Arab Saudi di Teheran. Hubungan diplomasi Arab Saudi dan Iran menjadi retak. Dampaknya lebih besar karena pada musim haji tahun 2016 masyarakat muslim Iran tidak dapat menunaikan ibadah Haji. Rivalitas terus berlanjut demi mencapai kepentingan, pengaruh dan reputasi di Timur Tengah.

Iran memaksimalkan bantuan finansial, militer, lobi politik dan 
kedekatan sekterianisme. Kemenangan Bashar Al-Assad adalah kemenangan Iran, sedangkan kekalahan Oposisi adalah kekalahan Arab Saudi. Kebijakan pemerintah Iran untuk mengambil tindakan dalam membantu Bashar alAssad mempunyai tujuan untuk kepentingan nasional. Tindakan suatu negara terhadap negara lain tentunya dipengaruhi oleh banyak faktor yang pada ujungnya adalah kepentingan nasional.

\section{Daftar Pustaka}

\section{Buku dan Jurnal}

Barakat, Halim, "Dunia Arab, Masyarakat, Budaya, dan Negara”. Bandung: Nusa Media, 2012

Burdah, Ibnu, "Islam Kontemporer, Revolusi dan Demokrasi". Malang: Intrans Publishing, 2014

Boening, Astrid B., "The Arab Spring. New York”. Springer, 2014

Goodarzi, Jubin M., "Syria and Iran, Diplomatic Alliance and Power Politic in The Middle

East". London: Tauris Academic Studies, 2006.

Jackson, Robert dan Robert Georg, "Pengantar Studi Hubungan
Internasional". Yogyakarta:

Pustaka Pelajar, 2009

Nadia von Maltzahn, “The Syriairan Axis Cultural Diplomacy and International Relations in the Middle East". New York: I.B Tauris, 2013

Nuechterlein, Donald E., "National Interests and Foreign Policy: A Conceptual Framework for Analysis and Decision-Making". (Brtish Journal of Intenational Studies ; Cambridge University Press, Vol. 2, No. 3 (Oct.,1976))

Keynoush, Banasheh, "Saudi Arabia and Iran, Friends or Foes?". New York: Plagrave, 2016

Kuncahyono, Trias, "Musim Semi di Suriah”. Jakarta: Buku Kompas, 2013

Kuncahyono, Trias, "Dari Damaskus ke Baghdad". Jakarta: Buku Kompas, 2004

Sahide, Ahmad, "Ketegangan Politik Syi'ah Sunni di Timur Tengah". Yogyakarta: The Phinisi Press, 2013

Sahide, Ahmad, “Gejolak Politik Timur Tengah”. Yogyakarta: The Phinisi Press, 2017

Sahide, Ahmad, “The Arab Spring: Membaca Kronologi dan Faktor Penyebabnya". (Journal UMY, Vol. 4, No. 2, 118-129, Mei 2015) 
Said Ali, As'ad, Al-Qaeda, "Tinjauan Sosial-Politik, Ideologi, dan Sepak Terjangnya”. Jakarta: LP3ES, 2014

Sulaeman, Dina, Prahara Suriah, "Membongkar Pesekongkolan Multinasional”. Jakarta: Pustaka Iiman, 2013

Setiawati, Siti Mutiah, "Aliansi

Militer Islam". Yogyakarta, Opini Kompas, Sabtu 09 Januari 2016

Sihbudi, M.Riza, "Bara Timur Tengah”. Bandung: Mizan, 1991

Sihbudi, M.Riza, "Menyandera Timur Tengah". Bandung: Mizan, 2007

Heriyanto, Husain, "Revolusi

Saintifik Iran”. Jakarta: UIPress, 2013

Yassin Kassab, Robbin, and alShami, Laila, "Burning Country, Syrian in Revolution and War". London: Pluto Press, 2016
Weiss, Michael and Hassan Hassan, "ISIS the Inside Story. Jakarta: Pernadamedia, 2015

Worren, Torstein Schiotz, Fear and Resistance, The Construction of Alawi Identity in Syria". Oslo : University Oslo, 2007

Koran Online

http://ismes.net

http://liputanislam.com

http://www.cnnindonesia.com

http://internasional.kompas.com

http://www.tribunnews.com/ internasional

https://international.sindonews. com

http://www.republika.co.id 